\title{
2021 Nobel Prize for mechanosensory transduction
}

\author{
Boris Martinac ${ }^{1} \mathbb{0}$ \\ Received: 15 December 2021 / Accepted: 2 February 2022 / Published online: 19 February 2022 \\ (c) The Author(s) 2022
}

\begin{abstract}
Written by someone who has worked in the mechanobiology field for close to 40 years, this commentary describes some historical background to the recent award of one-half of the Nobel Prize for Physiology or Medicine to Ardem Patapoutian for his discovery of the family of mechanosensitive Piezo ion channels, which function as mechanoreceptors feeling the environment in senses such as touch, pain, and proprioception.
\end{abstract}

Keywords Mechanosensitive ion channels $\cdot \mathrm{MscL} \cdot \mathrm{MscS} \cdot \mathrm{Piezo} 1 \cdot$ Piezo2

The shared Nobel Prize for Physiology or Medicine 2021 awarded to David Julius and Ardem Patapoutian for their respective breakthrough discovery of the vertebrate thermosensory TRP and mechanosensory Piezo ion channels recognizes the significance of the evolutionarily inherent ability that living organisms, from bacteria to humans, possess in sensing and responding to changes in their surrounding environment. This commentary is restricted to the prize relating to mechanosensitive ion channels.

Given the essential role of water for the existence of life and the presence of osmotic forces throughout the evolution of different life forms on Earth, mechanosensitive ion channels may be the oldest type of mechanoreceptors that evolved as primary signaling molecules supporting mechanosensory physiology of living organisms. Without the ability to perceive sensations of touch, hearing, sight, taste, smell, temperature, or pain, the outside world would cease to exist for vertebrate organisms, including humans, which emphasizes the importance of sensory input for the existence of life. To this point, Piezo2 members of the Piezo ion channel family serve as mechanoreceptors feeling the environment in senses such as touch, pain, and proprioception (Ernfors et al. 2021) (Fig. 1).

Boris Martinac

b.martinac@victorchang.edu.au

1 Molecular Cardiology and Biophysics Division, Victor Chang Cardiac Research Institute and St. Vincent's Medical School, Darlinghurst, NSW 2010, Australia

\section{Brief history}

The existence of mechanosensitive ion channels was first postulated in 1950 by Bernard Katz, who won the Nobel Prize for Physiology or Medicine in 1970 for his work on nerve physiology (Katz 1950). A quarter of a century later, Georg von Békésy, the 1961 Nobel Prize winner for Physiology or Medicine, discussed a possible existence of a mechanical receptor in frequency discrimination in the ear (Von Bekesy 1974). Several years later, Corey and Hudspeth suggested the existence of vertebrate mechanosensitive ion channels in bullfrog cochlear hair cells (Corey and Hudspeth 1979). Shortly after, thanks to the advent of the patch clamp technique (Hamill et al. 1981), the first single mechanosensitive ion channels were recorded from chick skeletal muscle by Guharay and Sachs (Guharay and Sachs 1984), from innervated muscle of Xenopus laevis by Brehm and collagues (Brehm et al. 1984) and from giant spheroplasts of E. coli by Martinac and colleagues (Martinac et al. 1987). It is to the credit of the Nobel Assembly, who duly recognized the pioneering studies on bacterial mechanosensitive channels (Fig. 2), which firmly established the existence of mechanosensitive channels in the late 1980s (Cox et al. 2018; Delcour et al. 1989; Martinac et al. 1987; Sukharev et al. 1994). This collective work ultimately paved the way to this year's Nobel Prize for the discovery of the Piezo mechanoreceptor family (Ernfors et al. 2021). 


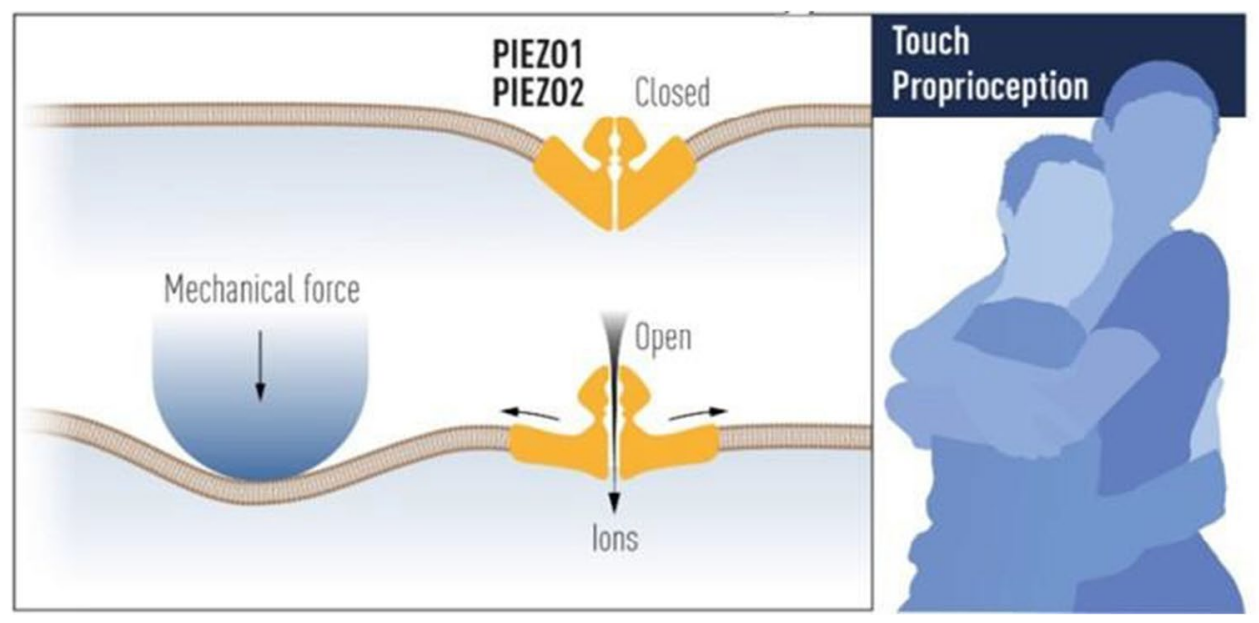

Fig. 1 Piezo family of ion channels. Piezo1 and Piezo2 are members of a new family of non-selective cation channels permeable to $\mathrm{Ca}^{2+}$ that are widely expressed in tissues of the hollow organs (lung, stomach, bladder, intestines) where they function as molecular mechanosensors. Cryo-electronmicroscopy structure of both chan-

\section{Discovery of Piezo1 and Piezo2}

Following on these initial discoveries, numerous mechanosensitive channels were functionally identified in cells and organisms from all three domains of life, Bacteria, Archaea, and Eukarya (Fig. 3) (Martinac and Cox 2017). The sheer number and occurrence of mechanosensitive channels eventually cast doubt on their biological reality and relevance, so that at some point they were suspected to be nothing more than artifacts of the patch-clamp recording technique. Their existence was finally put beyond doubt with the isolation, cloning, and determination of the 3D X-ray crystal structure of MscL, the bacterial mechanosensitive channel of large conductance from Mycobacterium tuberculosis, as the first channel of this kind identified at a molecular level (Chang et al. 1998; Hamill and Martinac 2001; Kefauver et al. 2020; Sukharev et al. 1994). There are now many examples of mechanosensitive channels that have been cloned in all types of organisms (Martinac and Cox 2017), and over the last 20 odd years, the information on their molecular identity and structure has become available.

The mammalian Piezo mechanosensitive channel family consisting of the Piezo1 and Piezo2 members was discovered just over a decade ago (Fig. 4) (Coste et al. 2010, 2012). Since their discovery, both channels have been extensively studied in laboratories all around the world. Both Piezo1 and Piezo2 are non-selective cationic nels revealed their curved structure in the membrane, which when flattened by mechanical force stretching the membrane, opens the channel pore (left panel). A hug is an example of the sense of touch in which Piezo2 functions as the mechanoreceptor (right panel) (Adopted and reproduced from (Ernfors et al. 2021) with permission)

channels permeable to $\mathrm{Ca}^{2+}$, whose gating can be stimulated by a variety of mechanical stimuli, including membrane stretching, compression, poking, and shear stress (Kefauver et al. 2020; Martinac and Cox 2017). Rapid growth in Piezo channel research very quickly led to determination of the 3D molecular structure of both Piezo1 (Guo and MacKinnon 2017) (Saotome et al. 2018; Zhao et al. 2018) and Piezo 2 (Wang et al. 2019) showing that both channels are homotrimers formed as a triskelion (viewed from the top) (Fig. 4, inset) (Guo and MacKinnon 2017). Like bacterial MscL and MscS channels (Cranfield et al. 2018), Piezo channels are also inherently mechanosensitive by sensing mechanical force directly through the lipid membrane (Cox et al. 2016; Syeda et al. 2016). However, although Piezo1 channel is gating according to the force-from-lipids paradigm (Martinac et al. 1990; Kung 2005; Teng et al. 2015), it has been shown that extracellular matrix and cytoskeleton can markedly modulate mechanical stimuli detected by this ion channel (Cox et al. 2019).

The significance of the Piezo channel discovery comes also from their implication in a number of mechanopathologies linked to malfunctioning of these ion channels in humans. Hereditary Xerocytosis, a familial anemia, is caused by a gain-of-function mutation in Piezo1 characterized by slowed inactivation resulting from three missense mutations and one recurrent duplication in the Piezo1 gene, with all mutations located at the $\mathrm{C}$-terminal half 
A

E. coli

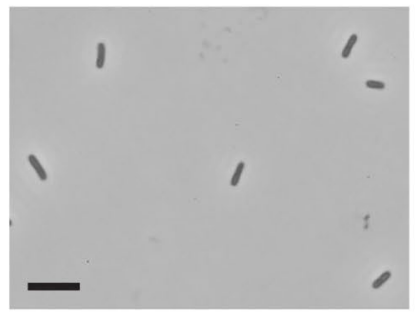

B

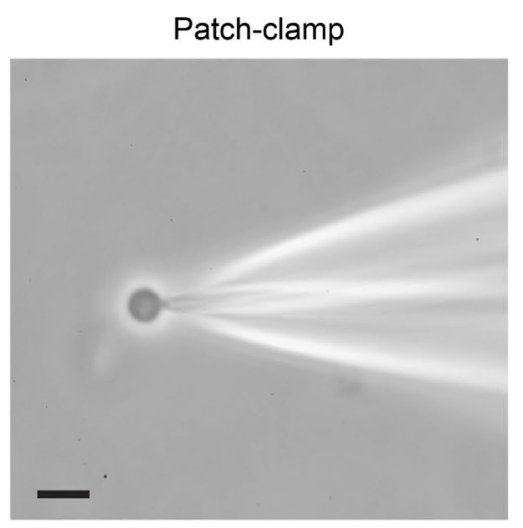

Long filament (snake)

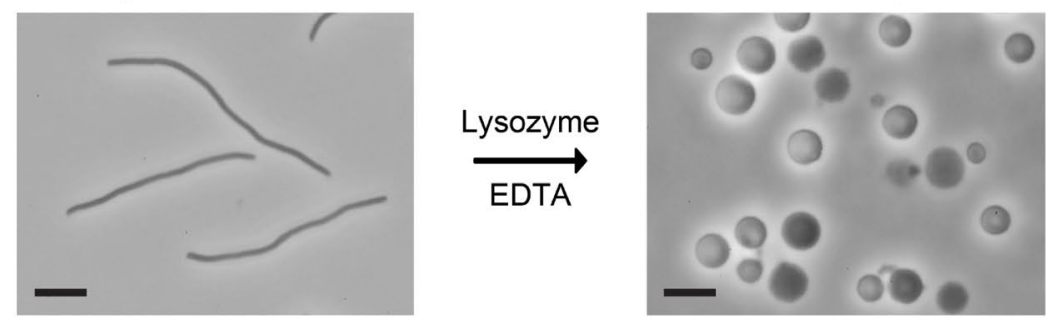

C

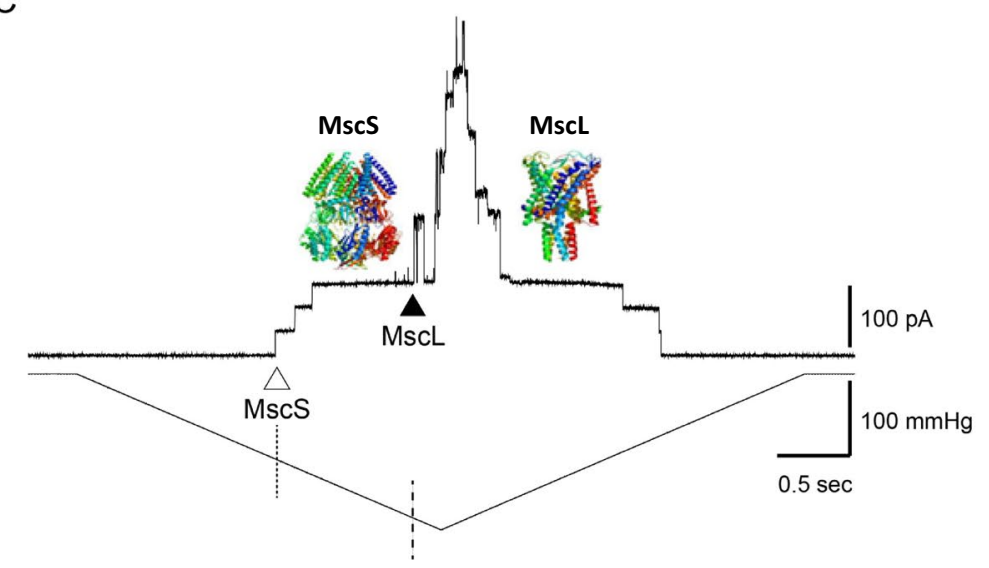

Fig. 2 Preparation of and patch-clamp recording from E. coli giant spheroplasts. The major steps during generation of giant spheroplasts from E. coli (scale bar corresponds to $5 \mu \mathrm{m}$ in all images) including generation of "snakes" and converting them into giant spheroplasts amenable to the patch clamp recording (top row). A phase contrast microphotograph of the patch pipette with a giant spheroplast at the tip (bottom row left). Activity of MscS and MscL channels of small and large conductance, respectively, recorded from an inside-out giant spheroplast patch (bottom row right). The upper trace shows the current traces of single MscS (open triangle) and MscL (filled triangle) channels opening upon application of negative pressure ramp (suction depicted by lower trace) applied to a patch pipette using a high-speed pressure clamp device. MscS activation threshold $(-114.5 \mathrm{mmHg})$ is indicated by the dotted line, whereas the activation threshold of MscL $(-195.2 \mathrm{mmHg})$ is indicated by the dashed line in good agreement with the previously reported results (Nomura et al. 2012; Yoshimura et al. 1999). Both MscS and MscL function as safety valves protecting bacteria from a sudden rise in cellular turgor pressure due to a hypoosmotic shock (Levina et al. 1999). Pipette potential was held at $+30 \mathrm{mV}$ (Reproduced with permission from (Martinac et al. 2013))

role that mechanical force, in all its manifestations, plays for living organisms. With regard to Piezo channels, the Prize embodies the significant role these mechanoreceptors play in a variety of physiological processes in vertebrates. It also recognizes the potential of both channels for the development of novel treatments for a wide range of mechano-channelopathies in the future. This shines a spotlight on the role mechanoreceptors play in the sustainability of different life forms, in a variety of environments, including microgravity for human colonization of outer space (Basirun et al. 2021). This year's Nobel Prize for discovery of the Piezo channel family provides significant impetus for research in mechanotransduction. 

tree. Life on Earth is organized in three kingdoms of living organisms based on small subunit tRNA sequences (Pace nosensitive channels that have been identified and characterized in each kingdom are listed next to the group of organisms in which they are found (arrows). Biological timescale from the time of the Earth's formation 4.6 billion years ago to the time of human origin (botoldest microfossils of prokaryotic cells are approximately 3.5 billion years old (Reproduced with permission from (Martinac and Cox 2017))
Fig. 3 Universal phylogenetic 1997). Examples of the mechatom right) (Woese 1994). The

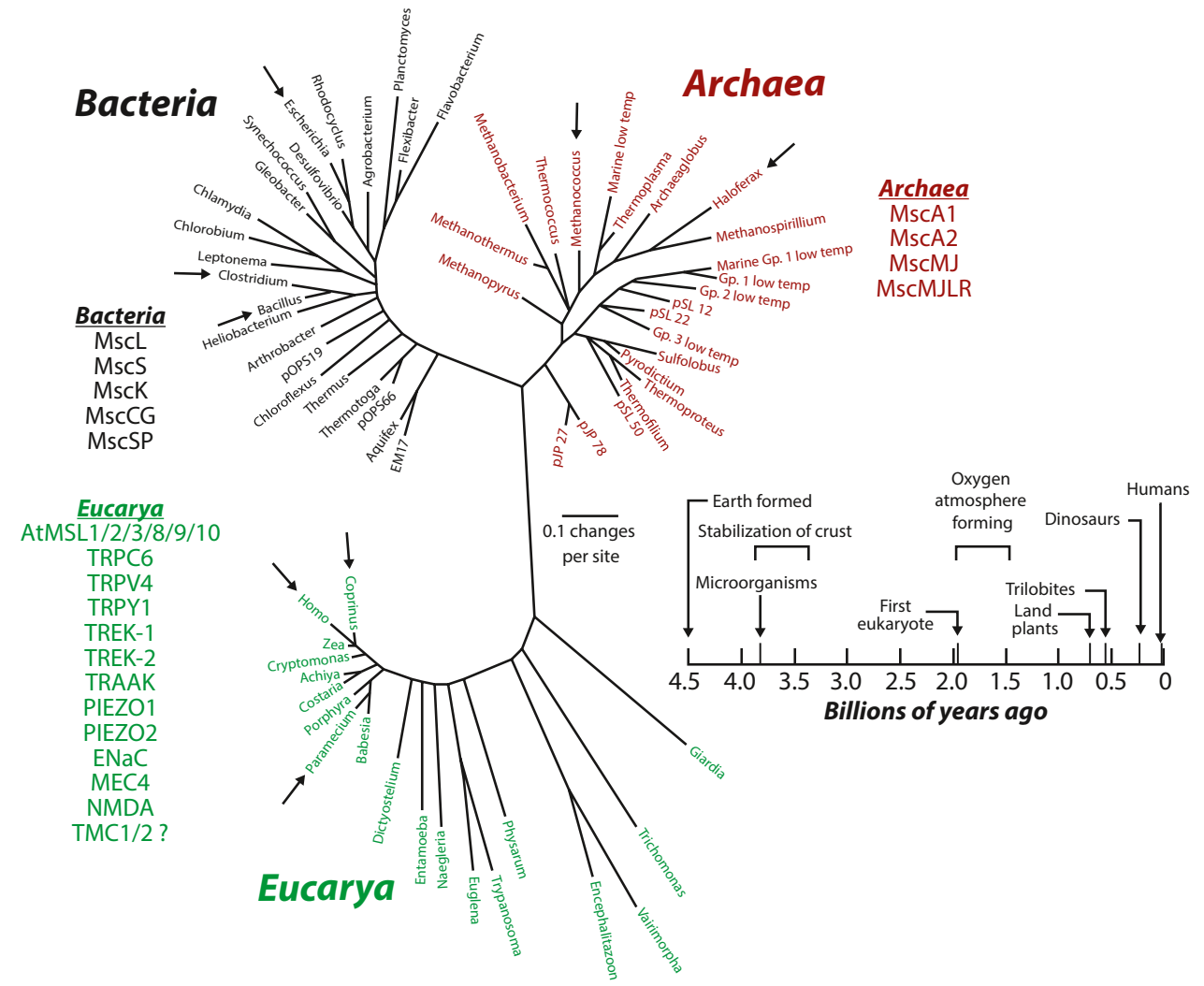

Gene silencing
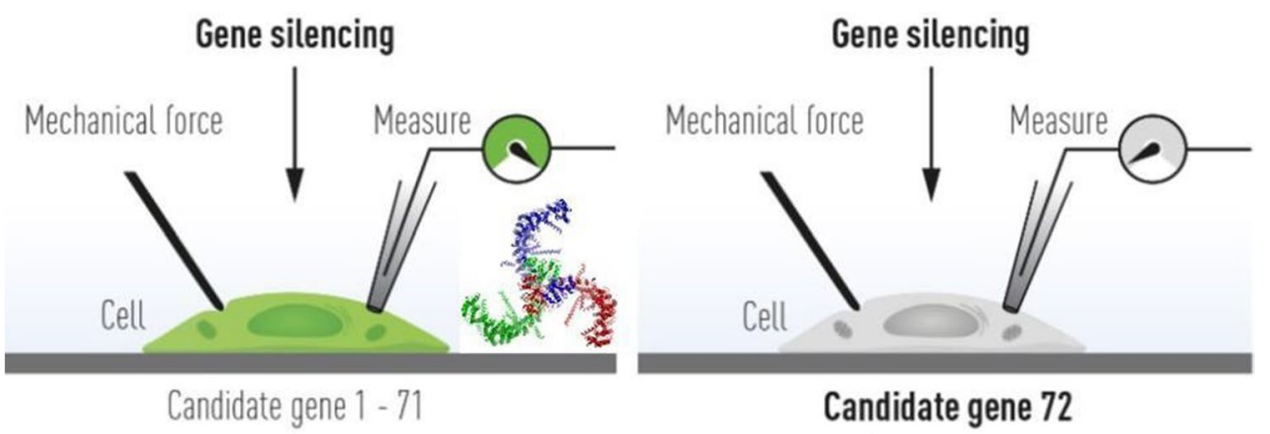

Fig. 4 The discovery of Piezo channels. Piezo ion channels were discovered by using gene silencing of 72 candidate genes in the mechanosensitive mouse cell line Neuro2a and searching for a loss of mechanoreception. This enabled discovery of the Piezo ion channel family.

Acknowledgements BM wishes to thank the members of the Nobel Assembly, Dr. Patrik Ernfors, Dr. Abdel El Manira, Dr. Per Svenningsson, and Dr. Thomas Perlmann, for their help with and constructive comments on this article. The author also thanks Dr. Cristobal dos Remedios and Adam Martinac for reading and editing the manuscript.

Funding Open Access funding enabled and organized by CAUL and its Member Institutions. The National Health and Medical Research Council of Australia is gratefully acknowledged for the Principal Research Fellowship (APP1135974) to BM.
Cryo-EM structure of the mouse Piezo1 triskelion with propeller-like arms composed of transmembrane helices forcing the membrane to curve (inset) (Reproduced and modified from (Ernfors et al. 2021) with permission)

\section{Declarations}

Ethical approval N/A

Consent to participate N/A

Consent to publish N/A

Conflict of interest The author declares no competing interests. 
Open Access This article is licensed under a Creative Commons Attribution 4.0 International License, which permits use, sharing, adaptation, distribution and reproduction in any medium or format, as long as you give appropriate credit to the original author(s) and the source, provide a link to the Creative Commons licence, and indicate if changes were made. The images or other third party material in this article are included in the article's Creative Commons licence, unless indicated otherwise in a credit line to the material. If material is not included in the article's Creative Commons licence and your intended use is not permitted by statutory regulation or exceeds the permitted use, you will need to obtain permission directly from the copyright holder. To view a copy of this licence, visit http://creativecommons.org/licenses/by/4.0/.

\section{References}

Albuisson J, Murthy SE, Bandell M, Coste B, Louis-Dit-Picard H, Mathur J, Fénéant-Thibault M, Tertian G, de Jaureguiberry J-P, Syfuss P-Y, Cahalan S, Garçon L, Toutain F, Rohrlich P-S, Delaunay J, Picard V, Jeunemaitre X, Patapoutian A (2013) Dehydrated hereditary stomatocytosis linked to gain-of-function mutations in mechanically activated PIEZO1 ion channels. Nat Commun 4:1884. https://doi.org/10.1038/ncomms 2899

Basirun C, Ferlazzo ML, Howell NR, Liu GJ, Middleton RJ, Martinac B, Narayanan SA, Poole K, Gentile C, Chou J (2021) Microgravity $\mathrm{x}$ radiation: a space mechanobiology approach toward cardiovascular function and disease. Front Cell Dev Biol 9:750775. https:// doi.org/10.3389/fcell.2021.750775

Brehm P, Kullberg R, Moody-Corbett F (1984) Properties of non-junctional acetylcholine receptor channels on innervated muscle of Xenopus laevis. J Physiol 350:631-648. https://doi.org/10.1113/ jphysiol.1984.sp015222

Chang G, Spencer RH, Lee AT, Barclay MT, Rees DC (1998) Structure of the MscL homolog from Mycobacterium tuberculosis: a gated mechanosensitive ion channel. Science 282(5397):2220-2226. https://doi.org/10.1126/science.282.5397.2220

Corey DP, Hudspeth AJ (1979) Response latency of vertebrate hair cells. Biophys J 26(3):499-506. https://pubmed.ncbi.nlm.nih.gov/ 318064

Coste B, Mathur J, Schmidt M, Earley TJ, Ranade S, Petrus MJ, Dubin AE, Patapoutian A (2010) Piezo1 and Piezo2 are essential components of distinct mechanically activated cation channels. Science 330(6000):55-60. https://doi.org/10.1126/science.1193270

Coste B, Xiao B, Santos JS, Syeda R, Grandl J, Spencer KS, Kim SE, Schmidt M, Mathur J, Dubin AE, Montal M, Patapoutian A (2012) Piezo proteins are pore-forming subunits of mechanically activated channels. Nature 483(7388):176-181. https://doi.org/10. 1038/nature 10812

Cox CD, Bae C, Ziegler L, Hartley S, Nikolova-Krstevski V, Rohde PR, $\mathrm{Ng}$ CA, Sachs F, Gottlieb PA, Martinac B (2016) Removal of the mechanoprotective influence of the cytoskeleton reveals PIEZO1 is gated by bilayer tension. Nat Commun 7(1):1-13. https://www. nature.com/articles/ncomms10366

Cox CD, Bavi N, Martinac B (2018) Bacterial mechanosensors. Annu Rev Physiol 80:71-93. https://doi.org/10.1146/annurev-physi ol-021317-121351

Cox CD, Bavi N, Martinac B (2019) Biophysical principles of ionchannel-mediated mechanosensory transduction. Cell Rep 29(1):1-12. https://doi.org/10.1016/j.celrep.2019.08.075

Cranfield CG, Kloda A, Nikolaev YA, Martinac AD, Ridone P, Bavi N, Bavi O, Petrov E, Battle AR, Nomura T, Rohde PR, Nakay Y, Rosholm KR, Cox CD, Baker MA, Martinac B (2018) Mechanosensitivity of ion channels. In: Roberts G, Watts A, Societies
European Biophysical (eds) Encyclopedia of Biophysics. Springer, Berlin. https://doi.org/10.1007/978-3-642-35943-9_376-1

De Felice D, Alaimo A (2020) Mechanosensitive Piezo Channels in Cancer: Focus on altered Calcium Signaling in Cancer Cells and in Tumor Progression. Cancers (Basel), 12(7):1780. https://doi. org/10.3390/cancers 12071780

Delcour AH, Martinac B, Adler J, Kung C (1989) Modified reconstitution method used in patch-clamp studies of Escherichia coli ion channels. Biophys J 56(3):631-636. https://doi.org/10.1016/ S0006-3495(89)82710-9

Ernfors P, El Manira A and Svenningsson P (2021) Discoveries of receptors for temperature and touch. The Nobel Assembly at Karolinska Institutet. Retrieved from https://lnkd.in/gRUQjPBb

Fotiou E, Martin-Almedina S, Simpson MA, Lin S, Gordon K, Brice G, Atton G, Jeffery I, Rees DC, Mignot C, Vogt J, Homfray T, Snyder MP, Rockson SG, Jeffery S, Mortimer PS, Mansour S, Ostergaard P (2015) Novel mutations in PIEZO1 cause an autosomal recessive generalized lymphatic dysplasia with non-immune hydrops fetalis. Nat Commun 6:8085. https://doi.org/10.1038/ ncomms 9085

Guharay F, Sachs F (1984) Stretch-activated single ion channel currents in tissue-cultured embryonic chick skeletal muscle. J Physiol 352:685-701. https://doi.org/10.1113/jphysiol.1984.sp015317

Guo YR and MacKinnon R (2017) Structure-based membrane dome mechanism for Piezo mechanosensitivity. Elife 6:e33660. https:// elifesciences.org/articles/33660

Hamill OP, Martinac B (2001) Molecular basis of mechanotransduction in living cells. Physiol Rev 81(2):685-740. https://doi.org/10. 1152/physrev.2001.81.2.685

Hamill OP, Marty A, Neher E, Sakmann B, Sigworth FJ (1981) Improved patch-clamp techniques for high-resolution current recording from cells and cell-free membrane patches. Pflugers Arch 391(2):85-100. https://doi.org/10.1007/BF00656997

Katz B (1950) Depolarization of sensory terminals and the initiation of impulses in the muscle spindle. J Physiol 111:261-282. https:// www.ncbi.nlm.nih.gov/pmc/articles/PMC1392822

Kefauver JM, Ward AB, Patapoutian A (2020) Discoveries in structure and physiology of mechanically activated ion channels. Nature 587(7835):567-576. https://doi.org/10.1038/s41586-020-2933-1

Kung C (2005) A possible unifying principle for mechanosensation. Nature 436:647-654. https://www.nature.com/articles/natur e03896

Levina N, Totemeyer S, Stokes NR, Louis P, Jones MA, Booth IR (1999) Protection of Escherichia coli cells against extreme turgor by activation of $\mathrm{MscS}$ and MscL mechanosensitive channels: identification of genes required for MscS activity. EMBO J 18(7):1730-1737. https://doi.org/10.1093/emboj/18.7.1730

Martinac B, Buechner M, Delcour AH, Adler J, Kung C (1987) Pressure-sensitive ion channel in Escherichia coli. Proc Natl Acad Sci U S A 84(8):2297-2301. https://doi.org/10.1073/pnas.84.8.2297

Martinac B, Adler J, Kung C (1990) Mechanosensitive ion channels of E. coli activated by amphipaths. Nature 348(6298):261263. https://pubmed.ncbi.nlm.nih.gov/1700306

Martinac B, Rohde PR, Cranfield CG, Nomura T (2013) Patch clamp electrophysiology for the study of bacterial ion channels in giant spheroplasts of E. coli. Methods Mol Biol 966:367-380. https:// doi.org/10.1007/978-1-62703-245-2_23

Martinac B and Cox CD (2017) Mechanosensory transduction: focus on ion channels. In Reference module in life sciences. Edition: Comprehensive biophysics: Elsevier (Amsterdam). https://doi. org/10.1016/B978-0-12-809633-8.08094-8

Nomura T, Cranfield CG, Deplazes E, Owen DM, Macmillan A, Battle AR, Constantine M, Sokabe M, Martinac B (2012) Differential effects of lipids and lyso-lipids on the mechanosensitivity of the mechanosensitive channels MscL and MscS. Proc Natl Acad Sci 
U S A 109(22):8770-8775. https://doi.org/10.1073/pnas.12000 51109

Pace NR (1997) A molecular view of microbial diversity and the biosphere. Science 276(5313):734-740. https://doi.org/10.1126/scien ce.276.5313.734

Saotome K, Murthy SE, Kefauver JM, Whitwam T, Patapoutian A, Ward AB (2018) Structure of the mechanically activated ion channel Piezo1. Nature 554(7693):481-486. https://doi.org/10.1038/ nature 25453

Sukharev SI, Blount P, Martinac B, Blattner FR, Kung C (1994) A large-conductance mechanosensitive channel in E. coli encoded by mscL alone. Nature 368(6468):265-268. https://doi.org/10. $1038 / 368265 \mathrm{a} 0$

Syeda R, Florendo MN, Cox CD, Kefauver JM, Santos JS, Martinac B, Patapoutian A (2016) Piezo1 channels are inherently mechanosensitive. Cell Rep 17(7):1739-1746. https://doi.org/10.1016/j. celrep.2016.10.033

Teng J, Loukin S, Anishkin A, Kung C (2015) The force-from-lipid (FFL) principle of mechanosensitivity, at large and in elements. Pflügers Archiv-Eur J Physiol 467(1):27-37. https://ur.booksc. eu/book/28183495/722229
Von Bekesy G (1974) Some biophysical experiments from fifty years ago. Annu Rev Physiol 36:1-18. https://doi.org/10.1146/annurev. ph.36.030174.000245

Wang L, Zhou H, Zhang M, Liu W, Deng T, Zhao Q, Li Y, Lei J, Li X, Xiao B (2019) Structure and mechanogating of the mammalian tactile channel Piezo2. Nature 573:225-229. https://www.nature. com/articles/s41586-019-1505-8

Woese CR (1994) There must be a prokaryote somewhere: microbiology's search for itself. Microbiol Rev 58(1):1-9. https://doi.org/ 10.1128/mr.58.1.1-9.1994

Yoshimura K, Batiza A, Schroeder M, Blount P, Kung C (1999) Hydrophilicity of a single residue within MscL correlates with increased channel mechanosensitivity. Biophys J 77(4):1960-1972. https:// doi.org/10.1016/S0006-3495(99)77037-2

Zhao Q, Zhou H, Chi S, Wang Y, Wang J, Geng J, Wu K, Liu W, Zhang T, Dong M-Q, Wang J, Li X, Xiao B (2018) Structure and mechanogating mechanism of the Piezo1 channel. Nature 554(7693):487-492. https://doi.org/10.1038/nature25743

Publisher's note Springer Nature remains neutral with regard to jurisdictional claims in published maps and institutional affiliations. 